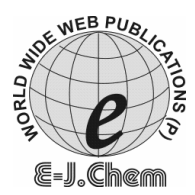

\title{
Potentiometric Studies on Transition Metal Complexes of Substituted Derivative of Coumarin-Part 1
}

\author{
K. B. VYAS, G. R. JANI ${ }^{\S}$ and M. V. HATHI ${ }^{*}$ \\ Department of Chemistry, \\ Government Science College, Gandhinagar, Gujarat, India. \\ ${ }^{\S}$ Department of Chemistry, M. N. College, Visanagar, Gujarat, India. \\ kirankartik@yahoo.com
}

Received 22 February 2009; Accepted 4 April 2009

\begin{abstract}
The formation constants of binary complexes of $\mathrm{d}^{10}$ metal ions $\mathrm{Cu}(\mathrm{II}), \mathrm{Ni}(\mathrm{II}), \mathrm{Co}(\mathrm{II})$ and $\mathrm{Mn}(\mathrm{II})$ with 3-[\{3-(3'-chloro phenyl $\}$-prop-2-enoyl]4-hydroxy-6-methyl-2H-chromen-2-one have been studied by using IrvingRossoti method at constant temperature $30 \pm 1{ }^{\circ} \mathrm{C}$ and ionic strength $\mu=0.1 \mathrm{M}$ $\mathrm{dM}^{-3}$ was held constant using sodium nitrate as an electrolyte. The factors influencing formation and stabilities of binary complexes have been discussed.
\end{abstract}

Keywords: Binary Complexes, Stability Constants, Metals, Ligand, pH metric titration.

\section{Introduction}

The transition metals have tendency to form co-ordination compounds with Lewis bases with groups which are able to donate an electron pair. Some of the coumarins show distinct physiological photodynamic and bacteriostatic activities ${ }^{1}$ and placed for many diverse uses ${ }^{2}$. Their chelating characteristics have long been observed and the bacteriostatic activity seems to be due to chelation. The physicochemical studies ${ }^{3,4}$ of the coumarins with chelating group at appropriate position and their metal complexes reveal that the ligand can be used as potential analytical reagents ${ }^{5}$.

Mandakmare $\mathrm{U}$ and Narwade $\mathrm{M} \mathrm{L}^{6}$ studied the determination of stability constants of $\mathrm{Cu}(\mathrm{II})$ chelates with some substituted coumarins at $0.1 \mathrm{M}$ ionic strength $\mathrm{pH}$ metrically and Vyas K B et al. ${ }^{7}$ have synthesized $\mathrm{Cu}(\mathrm{II}), \mathrm{Ni}(\mathrm{II}), \mathrm{Co}(\mathrm{II})$ and $\mathrm{Mn}(\mathrm{II})$ metal complexes of hydroxy coumarin and reported their stability constants. Chalcones are useful for the detection of $\mathrm{Fe}(\mathrm{II})^{8}$ and $\mathrm{Ca}(\mathrm{II})$ ions in presence of $\mathrm{Ba}$ and $\mathrm{Sr}$ as it reacts with a number of metal ions. 
Chalcones of 4-hydroxy coumarin derivative is known for their biological activity ${ }^{9}$ and also acts as a good chelating agent due to their O-O electron donor system. In the present investigation the formation constants of binary chelates of above mentioned ligand with $\mathrm{Cu}(\mathrm{II}), \mathrm{Ni}(\mathrm{II}), \mathrm{Co}(\mathrm{II})$ and $\mathrm{Mn}$ (II) have been determined $\mathrm{pH}$ metrically at the temperature $30 \pm 0.1^{\circ} \mathrm{C}$ and $0.1 \mathrm{M} \mathrm{NaNO}_{3}$ ionic strength.

\section{Experimental}

The ligand compound (I) was prepared (Scheme 1) and purified by the method reported in the literature ${ }^{10}$. The solution of the compound (I) was prepared in A R Grade 1,4 dioxane. The metal solution were prepared by dissolving metal nitrate of A R Grade in double distilled water and standardized by EDTA ${ }^{11}$. The other reagents $\mathrm{NaNO}_{3}(\mathrm{BDH}), \mathrm{NaOH}$ $(\mathrm{BDH})$ and $\mathrm{HNO}_{3}(\mathrm{BDH})$ of $\mathrm{A} \mathrm{R}$ Grade were used and their solutions were prepared in double distilled water and standardized by the usual methods.<smiles>CC(=O)c1c(O)c2cc(C)ccc2oc1=O</smiles>

3-Acetyl - 4-hydroxy -6-methylcoumarin (I)

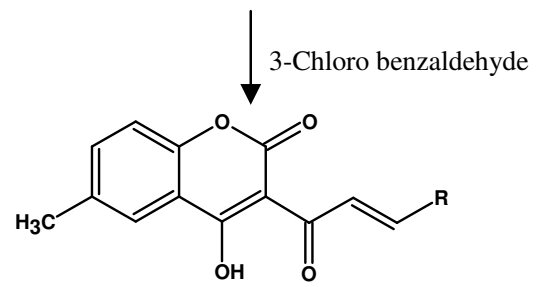

3-[\{3-(3'-Chloro phenyl) \}-prop-2-enoyl]-4-hydroxy-6-methyl-2H-chromen-2-one [Where $\mathrm{R}=3^{\prime}$-Chloro phenyl]

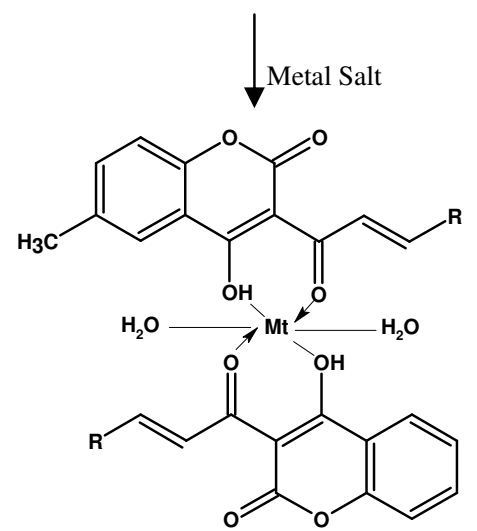

Bis -(3-[\{3-(3'-Chloro phenyl) $\}$-prop-2-enoyl]-4-hydroxy-6-methyl-2H-chromen-2-one) $\mathrm{Mt}^{+2}$ Complex(II).

Scheme 1.

Proton ligand formation constants of the ligand and metal ligand formation constant of binary system were determined $\mathrm{pH}$ metrically by Irving-Rosootti ${ }^{12,13}$ titration technique. 
The metal ligand ratio was maintained at 1:5. The ligand concentration was maintained at $2.00 \times 10^{-3} \mathrm{M}$ and the metal ion concentration was maintained at $4.00 \times 10^{-4} \mathrm{M}$. The total volume was maintained at $50 \mathrm{~mL}$. The ionic strength was maintained at $0.1 \mathrm{M}$ by adding requisite amount of sodium nitrate in binary titrations. The stability constants were calculated by Irving and Rossotti method. All the solutions were titrated against $0.1 \mathrm{M}$ sodium hydroxide solution. $60 \%$ of aqueous 1,4 dioxane medium was maintained in all the titrations. $\mathrm{pH}$ meter reading in $60 \%$ (v/v) aqueous 1,4 dioxane were corrected by the method of Van-uitert and Hass ${ }^{14}$. From the titre values the $\log \mathrm{K}$ values were evaluated.

\section{Results and Discussion}

The solution chemistry of first transition series is very interesting. The following factors explain satisfactorily the overall characteristics of stability and other aspects; ionization enthalpies of metal atoms, ionic radius, electronic structure of metal ions, nature of ligands involved in $\mathrm{d} \pi$ - $\mathrm{p} \pi$ inter actions, nature of solvent $e t c$.

In the present investigation, manganese tri-positive state is less stable than di-positive. The stability shown by $\mathrm{Mn}^{2+}$ with the ligand compound (I) is the lowest in the selected ions. This is due to the lower charge and specific behaviour of metal ion.

$\mathrm{Co}(\mathrm{II}), \mathrm{Ni}(\mathrm{II})$ and $\mathrm{Cu}(\mathrm{II})$ metal ions were selected for equilibrium study in water with ligand, which co-ordinates through $\mathrm{O}$ and $\mathrm{O}$ of $-\mathrm{OH}$ and $>\mathrm{C}=\mathrm{O}$ respectively.

$\mathrm{Cu}$ (II) has greater lattice and solution energies, hence higher formation constant for complexes of $\mathrm{Cu}(\mathrm{II})$ ions is observed amongst three, $\mathrm{Cu}$ (II) shows higher stability as expected. Co(II) complexes with ligand is more stable than corresponding $\mathrm{Ni}$ (II) complexes. This is attributed to the size of the metal ions.

The orders of stability constants of the metal chelates under investigation are $\mathrm{Mn}(\mathrm{II})<\mathrm{Co}(\mathrm{II})<\mathrm{Ni}(\mathrm{II})<\mathrm{Cu}(\mathrm{II})$ which is in conformity with the Irving Williams natural order of stabilities ${ }^{15}$.

The acid dissociation constants and the binary formation constants so obtained are presented in Table 1. It was established that the association of proton is affected by strength of hydrogen bonding between oxygen of hydroxy group and carbonyl group. Stronger the hydrogen bond, lesser will be the dissociation and hence less is the acid character of $-\mathrm{OH}$ group.

Table 1. Proton ligand and binary metal ligand stability constants of metal complexes at temperature $30 \pm 0.2{ }^{\circ} \mathrm{C}$.

\begin{tabular}{cllll}
\hline Ligand & \multicolumn{4}{c}{ Metal - ligand formation constants } \\
\cline { 2 - 5 } $\mathrm{pK}^{\mathrm{H}}$ Values & \multicolumn{1}{c}{$\mathrm{Cu}$} & \multicolumn{1}{c}{$\mathrm{Ni}$} & $\mathrm{Co}$ & $\mathrm{Mn}$ \\
\hline $\log \mathrm{pK}_{1}{ }^{\mathrm{H}}=11.00$ & $\log \mathrm{K}_{1}=11.00$ & $\log \mathrm{K}_{1}=11.00$ & $\log \mathrm{K}_{1}=11.00$ & $\log \mathrm{K}_{1}=11.00$ \\
$\log \mathrm{pK}_{2}{ }^{\mathrm{H}}=03.76$ & $\log \mathrm{K}_{2}=11.18$ & $\log \mathrm{K}_{2}=11.15$ & $\log \mathrm{K}_{2}=10.65$ & $\log \mathrm{K}_{2}=09.23$ \\
& $\log \beta=22.18$ & $\log \beta=22.15$ & $\log \beta=21.65$ & $\log \beta=20.23$ \\
\hline
\end{tabular}

In all the systems under investigation the metal titration curves were depressed below the ligand titration curves. This was expected in the complex formation of the metal ion with the ligand during the metal titration in present of excess of the ligand (nearly five times more).

Thus the binary $\mathrm{ML}_{2}\left(\mathrm{H}_{2} \mathrm{O}\right)_{2}$ complexes have been studied to determine their stability. It is interesting because these data are useful to understand the role of metal ions in various biochemical reactions and their role as an analytical reagent. 


\section{Acknowledgement}

The authors express their gratitude to Dr. M. V. Hathi, the research guide for providing the necessary research facilities and research guidance

\section{References}

1. Hankare P P, Jagtap A H, Battase P S and Naravne S R, J Indian Chem Soc., 2002, 79(5), 440-441.

2. Glein K T, U. S. Patent 2740761 Apr. 3, Chem Abstr., 1956, 50, 1333788c.

3. Katyal M and Singh H B, Talanta, 1968, 15, 1054.

4. Kohli N, Ph D Thesis, Delhi University, 1974.

5. Dave S M, Studies on organic compounds as an analytical reagent, $\mathrm{Ph} \mathrm{D}$ thesis, Saurashtra University, 2002.

6. Mandakmare A U and Narwade M L, Orient J Chem. 1999, 15(1), 173-175.

7. Vyas K B, Nimavat K S, Jani G R and Hathi M V, Res J Chem. and Environ., 2009, 13(1), 35-36.

8. Syamasundar K, Proc Indian Acad Sci., 1964, 59A, 241.

9. Mulvand V V, Bhagat R D, Indian J Heterocyclic Chem.,1999, 9, 15.

10. Hermes S A, Chem Abstr., 1968, 70, 964224.

11. Vogel A I, Text book of Quantitative practical inorganic chemistry, ELBS, 1984.

12. Irving H M and Rossotti H S, J Chem Soc., 1953, 3397.

13. Irving H M and Rossotti H S, J Chem Soc., 1954, 2904.

14. Van Uitert L G and Hass C G, J Am Chem Soc., 1953, 75, 451.

15. Irving H and William R J P, J Chem Soc., 1953, 8, 3192. 


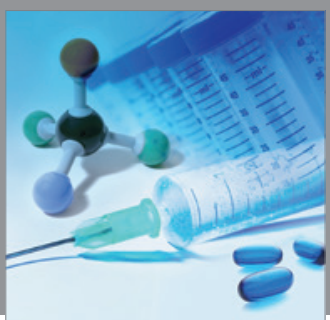

International Journal of

Medicinal Chemistry

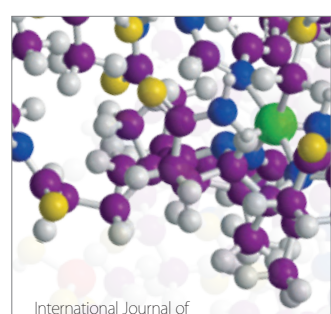

Carbohydrate Chemistry

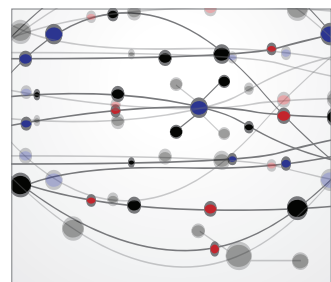

The Scientific World Journal
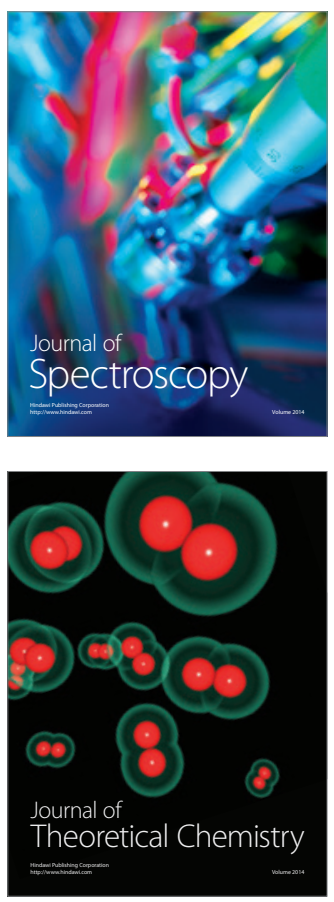
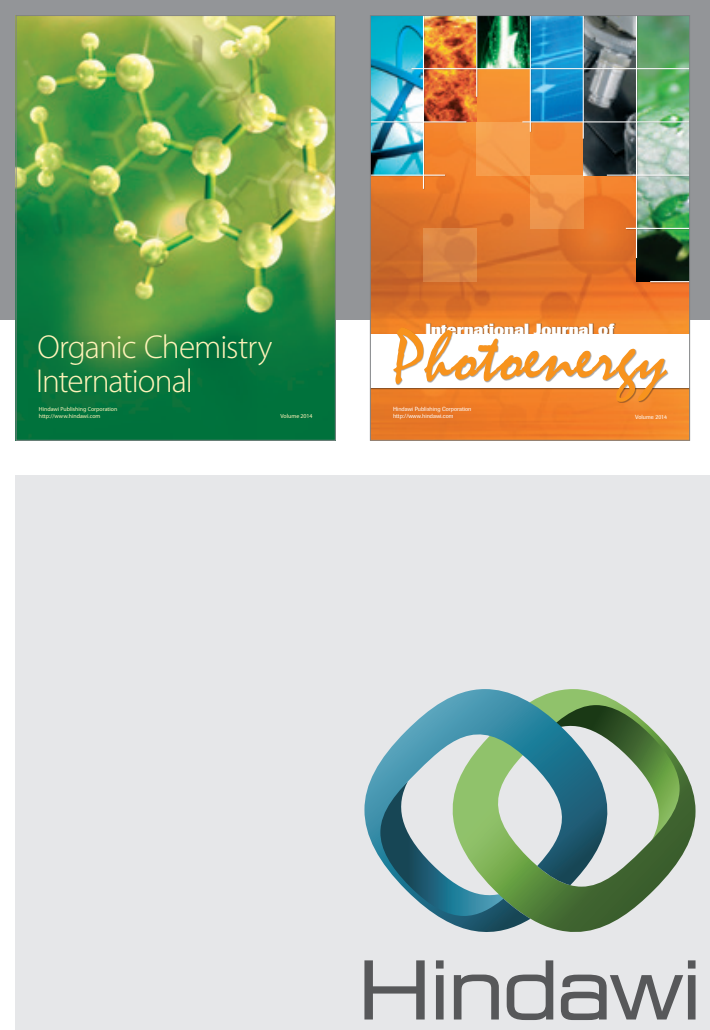

Submit your manuscripts at

http://www.hindawi.com
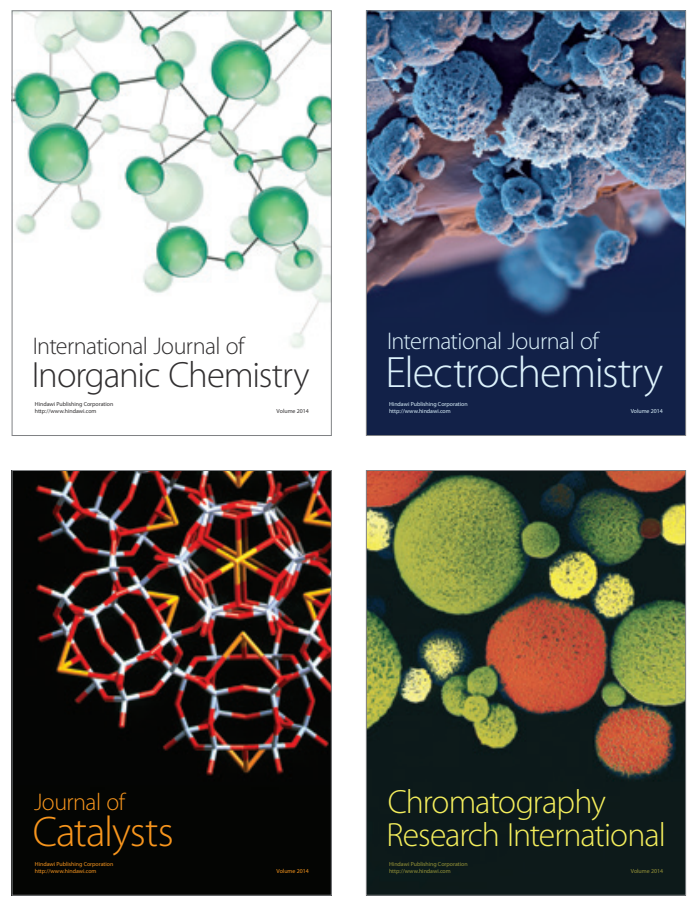
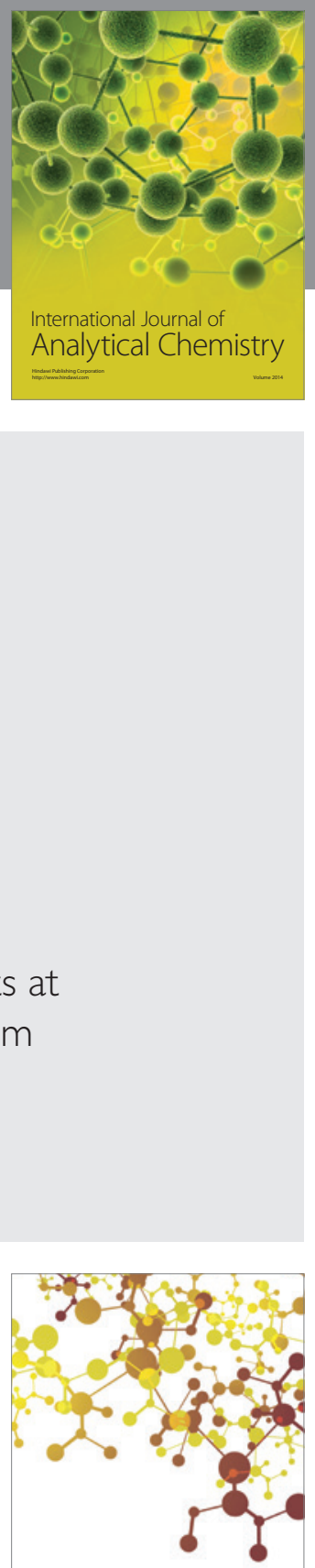

Journal of

Applied Chemistry
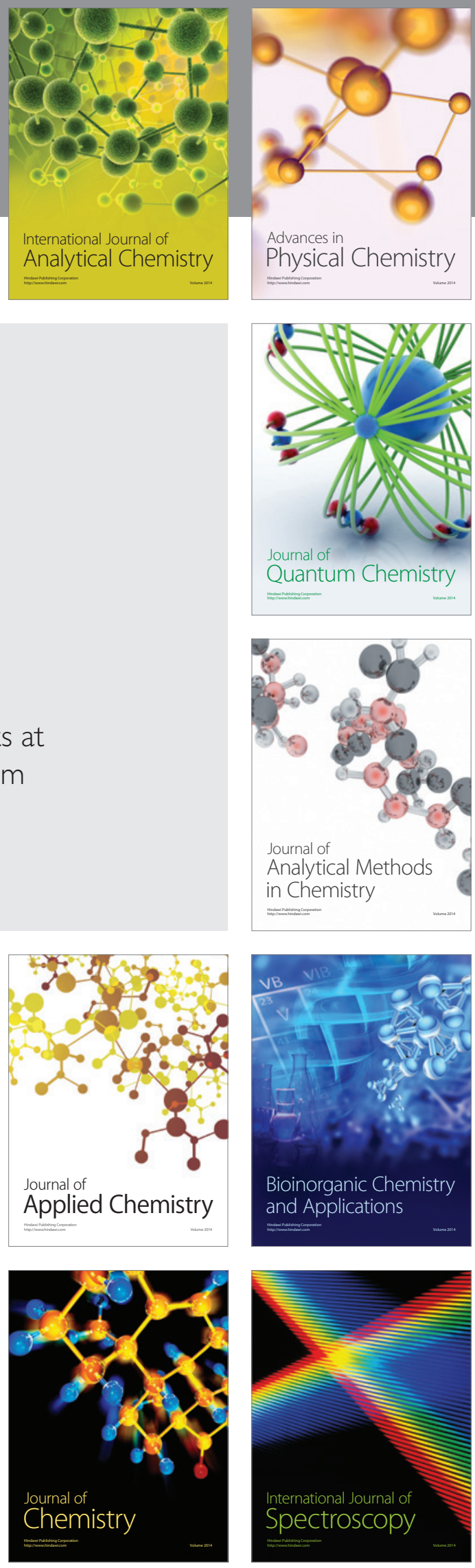